\title{
Factors Affecting the Academic Performance of Undergraduate Medical Students at a Medical Institute of Northern India
}

\author{
Vidya Rani ${ }^{(\text {(D) }}$, Naresh Pal Singh ${ }^{1 *(D)}$, Prem Prakash Bharti ${ }^{1}$ (iD) \\ ${ }^{1}$ Department of Community Medicine, Uttar Pradesh University of Medical Sciences, Saifai, PIN code 206130 Etawah, Uttar Pradesh, India
}

\begin{tabular}{|c|c|}
\hline Article Info & Abstract \\
\hline dol & $\begin{array}{l}\text { Background \& Objective: Academically good students become good citizens and good citizens make a better } \\
\text { society. They are the prospective heirs of a nation, so those factors that influence their academic performance } \\
\text { should be taken into consideration to build up an integrated and developed nation. }\end{array}$ \\
\hline $\begin{array}{l}\text { Article history: } \\
\text { Received } 19 \text { Jul } 2020 \\
\text { Accepted } 29 \text { Sep } 2020 \\
\text { Published } 01 \text { Jan } 2021 \\
\text { Keywords: } \\
\text { Academic performance, } \\
\text { Medical students, Predictors, } \\
\text { Professional Examination }\end{array}$ & $\begin{array}{l}\text { To find out the factors that potentially influence academic excellence of medical students. } \\
\text { Materials and Methods: A cross-sectional study was carried out among medical students of final year. A } \\
\text { predesigned, pretested, structured, self-administered questionnaire was used to collect information. To identify } \\
\text { significant predictors of students' academic performance, Uni-variate and multivariate binary logistics analysis } \\
\text { were done. } \\
\text { Results: A total of } 149 \text { students were interviewed. Analysis of average marks in all three professionals revealed }\end{array}$ \\
\hline $\begin{array}{l}\text { *Corresponding author: } \\
\text { Naresh Pal Singh, Department of } \\
\text { Community Medicine, } \\
\text { Uttar Pradesh University of Medical } \\
\text { Sciences, Saifai, PIN code } 206130 \\
\text { Etawah, Uttar Pradesh, India. } \\
\text { Email: nareshpalsingh@gmail.com }\end{array}$ & $\begin{array}{l}\text { below } 60 \% \text {. In univariate binary logistic regression analysis factors such as gender, area of schooling up to } \\
\text { class } 12 \text { th, education and occupation of parents, history of alcohol consumption and adequate sleep were found } \\
\text { to be significant predictors for students' academic performance. In multivariate binary logistics regression } \\
\text { analysis, only gender was the significant predictor. } \\
\text { Conclusion: After completing their basic school education, when students enter the professional medical } \\
\text { colleges, there are some modifiable and some non-modifiable factors which have great impact on their } \\
\text { academic performance. These can be dealt accordingly by the institutional authorities to have better academic } \\
\text { performance of the students. }\end{array}$ \\
\hline (1) 8 & $\begin{array}{l}\text { is is an original open-access article distributed under the terms of the Creative Commons Attribution-noncommercial } 4.0 \\
\text { which permit copy and redistribution of the material just in noncommercial usages with proper citation }\end{array}$ \\
\hline
\end{tabular}

\section{Introduction}

Schools, colleges, and universities have no worth without students. For an educational institute, students are the most important asset. The social and economic development of a country largely depends upon the academic performance of students. Their academic achievement plays an important role in producing the best quality graduates who will become great administrator and workforce for the country. The performance of students is a crucial factor in the development of quality graduates which in turn enhances the economic growth of the country and hence it strengthens the nation (1).

The primary goal of medical institution is to generate skilled doctors (2). Employers also take academic achievement as one of the major factors in recruiting graduates (3). Thus, students have to put the greatest effort in their study to obtain good marks and to prepare themselves for future opportunities in their career and at the same time to fulfil the employer's demand (4). Examination is an important factor for assessing the academic performance of the students. There are various factors which create hindrances in the performance of the students (5) and these may be external and internal factors including gender, age, study habits, discipline, class attendance, the contribution of a teacher in academic achievement of students, time management, socialization, sleep patterns, partying behaviour, socio-economic status, educational background of parents etc (6). These factors strongly influence students' performance, but these vary from person to person and country to country (7). Undergraduate medical education in India and along with many developing nations is facing new challenges today. Despite giving best teaching to the medical students, it is observed that the performance of 
students as well as doctors has been largely declining (8).

Students' academic performance measurements has received considerable attention in previous researches. Many studies have been conducted to identify the factors that affect (positively and negatively) students' achievements as well as to examine predictors of success in medical schools. The aim of this work is to explore the factors that potentially influence excellence of medical students.

\section{Materials and Methods}

A cross-sectional study was conducted among final-year (part two) MBBS students at a medical institution in Northern India from September 2019 to February 2020. Predesigned, pretested, structured, self-administered questionnaire was used for collection of information regarding general demographic profile and factors affecting the academic performance of undergraduate medical students. Questionnaire comprised of variables like age, sex, the area from where they belong, parents' occupation and education. Income of the family and total members in the family were enquired to assess socio-economic status using modified B.G. Prasad classification. Detailed information about lifestyle and personal habits of students were also collected like smoking habit, consumption of alcohol, involvement in extracurricular activity, presence of medical illness, hours of sleep, insomnia etc.

Before start of the study, validity of instrument used for data collection was ensured firstly by prior thorough study of the relevant literature available both online and offline; secondly by in-depth discussion with experts in the field of medical education like Dean of the medical institution and heads of the concerned departments and lastly the questionnaire was validated by doing pilot study among twenty students studying in the 2nd professional and were not the part of our study. The study commenced after taking approval from institutional ethical committee. The questionnaire was distributed to all students simultaneously while seated in the lecture-hall and not given any scope for discussion during answering. The students absent on that day were contacted through telephonic communication. Data was collected from 149 medical students after taking their informed written consent. The study subjects were assured that their information will not be disclosed at any level and will only be used for analysis and evaluation as per the study objectives.

Students' academic performance was analysed on the basis of their overall average score of their first year, second year, and mini professional examination marks. The dependent variable was academic performance which was categorised into two binary outcomes, good and average performance. Students having average examination score in all three professional examinations $60 \%$ or more was categorised as "Good" performance and lower than $60 \%$ as "average" performance. In all the medical institutions in India, all the medical students have to secure at least $50 \%$ marks in the concerned subject to pass and marks above $60 \%$ are considered as first division, hence this categorisation for academic performance was used in the present study. The data were tabulated and analysed using IBM SPSS software version 21 by statistical tools like one-way ANOVA, univariate and multivariate binary logistic regression analysis at $95 \%$ confidence interval with $P<0.05$ as level of significance to identify the factors influencing the academic performance.

\section{Results}

A total of 149 students in the final professional (Part second) were interviewed. Study participants comprised of $98(65.8 \%)$ male students and 51 (34.2\%) female students. Mean \pm SD age of students was $25.03 \pm 1.71$ years. Eighty-seven (58.4\%) students were from the urban and 62 (41.6\%) students from the rural background. Out of 149 students, $9(6.1 \%)$ in 1st year, $15(10.1 \%)$ in 2nd year and $5(3.3 \%)$ in final professional (part one) examination passed in the second attempt.

Table-1 depicts that good academic performance (marks $\geq 60 \%$ ) in first, second and final (part-1) professional examinations was achieved by 99 (64.4\%), 49 (32.9\%) and 45 (30.2\%) 
students, respectively. These findings suggest that the academic performance was reduced gradually to almost half in second and third year. Considering the average marks of all three professionals, only 59 (39.6\%) students scored equal to or more than $60 \%$ whereas 90 (60.4\%) students had marks below $60 \%$.

Table 1: Professional-wise distribution of undergraduate medical students on their academic performance $(\mathrm{N}=149)$

\begin{tabular}{ccccc}
\hline & First Year & Second Year & Final Year & $\begin{array}{c}\text { Average of all three } \\
\text { Professional }\end{array}$ \\
Academic performance & Professional & Professional & Professional (part-1) & n (\%) \\
& $\mathbf{n}(\%)$ & $\mathbf{n}(\%)$ & $45(30.2)$ & $59(39.6)$ \\
Average $(<60 \%$ marks) & $99(66.4)$ & $49(32.9)$ & $104(69.8)$ & $90(60.4)$ \\
\hline
\end{tabular}

Table-2 reveals that mean \pm SD of marks obtained by students in first, second and final year (part 1) was $61.48 \pm 6.11,58.07 \pm 4.69$ and $57.96 \pm$ 3.82 respectively. This difference between mean of marks obtained and year of professional examination was found to be statistically significant $(P 0.001)$.

Table 2. Association between mean academic performance and Year wise- professionals

\begin{tabular}{ccccc}
\hline Marks & First Year & Second Year & Final Year & One Way \\
& Professional & Professional & Professional (part-1) & ANOVA \\
\hline Mean & 61.48 & 58.07 & 57.96 & $P 0.001$ \\
SD & 6.11 & 4.69 & 3.82 & \\
\hline
\end{tabular}

Table-3 reveals that out of $59(39.6 \%)$ students who had overall good academic performance in all three professionals, 19 (32.2\%) were male and 40 $(67.8 \%)$ were female. In univariate binary logistic regression analysis, crude odds ratio (COR) for gender was found to be 0.066 which indicates that male students had $93.4 \%$ less likelihood of getting marks equal to or more than $60 \%$ than female students. Considering the place of education up to class 12 th of the study subjects, it was observed that $19(32.2 \%)$ students out of the 59 with good performance in their examination and 48 (53.3\%) out of the 90 students with average performance had completed education from rural area. The students who were educated up to class 12 th from rural area had $58.4 \%$ less chances of good performance than those students who were educated from the urban area (crude odds ratio $=0.416, P 0.012)$. There were only $8(13.6 \%)$ students who faced difficulty in English speaking and writing among good performance students while 24 (26.75\%) (just double) of the 90 students 
who had average academic performance, were not competent in English language. With respect to fathers' occupation and good academic performance, the estimated crude odds ratio was 1.31 which indicates that those students whose fathers were employed, had 1.31 times more chances of better performance than those students whose father were unemployed.

To ascertain the impact of smoking and alcohol consumption on academic performance among students. It was observed that there was no statistically significant effect of smoking on academic performance ( $P$ 0.560). Among those students who scored good marks in their examination, only $5(8.5 \%)$ students consumed alcohol while 28 (31.1\%) students were consuming alcohol among the students with average performance. The students who consumed alcohol had $80 \%$ less likelihood of getting good marks than those students who did not consume alcohol (crude odds ratio $=0.205, P 0.002$ ).

In analysis of academic performance with insomnia and sleeping time $<7$ hours, crude odds ratio was found to be $0.408, P 0.045$ and 0.402 , $P 0.010$ respectively which explains that those students who had insomnia and sleeping duration less than 7 hours had $59.2 \%$ and $60 \%$ respectively less likelihood of good academic performance than other students who were not facing these problems. The students involved in extracurricular activity had $60 \%$ less chances of having good marks than those who were not involved (crude odds ratio $=0.392, P 0.010$ ).

Table 3. Univariate Binary Logistic Regression analysis between various factors and academic performance of undergraduate medical students

\begin{tabular}{|c|c|c|c|c|c|c|c|}
\hline \multirow{6}{*}{ Variables } & \multirow{6}{*}{ Sub groups } & & & \multicolumn{4}{|c|}{ Univariate binary logistic regression } \\
\hline & & \multicolumn{2}{|c|}{$\begin{array}{c}\text { Average marks in all three } \\
\text { Professional years }\end{array}$} & \multirow{5}{*}{ Significant } & \multirow{5}{*}{$\operatorname{Exp}(\beta)$} & \multicolumn{2}{|c|}{$\begin{array}{c}95 \text { \% C.I. for } \\
\operatorname{EXP}(\beta)\end{array}$} \\
\hline & & Good & Average & & & \multirow{4}{*}{ Lower } & \multirow{4}{*}{ Upper } \\
\hline & & $(\geq 60 \%)$ & $(<60 \%)$ & & & & \\
\hline & & $N=59$ & $\mathrm{~N}=90$ & & & & \\
\hline & & n (\%) & n (\%) & & & & \\
\hline \multirow{3}{*}{ Gender } & Male & $19(32.2)$ & $79(87.8)$ & \multirow{3}{*}{0.001} & \multirow{3}{*}{0.066} & \multirow{3}{*}{0.029} & \multirow{3}{*}{0.152} \\
\hline & & & & & & & \\
\hline & Female & $40(67.8)$ & $11(12.2)$ & & & & \\
\hline \multirow{3}{*}{$\begin{array}{c}\text { Place of } \\
\text { Education up to } \\
\text { class } 12^{\text {th }}\end{array}$} & Rural & $19(32.2)$ & $48(53.3)$ & \multirow{3}{*}{0.012} & \multirow{3}{*}{0.416} & \multirow{3}{*}{0.209} & \multirow{3}{*}{0.825} \\
\hline & & & & & & & \\
\hline & Urban & $40(67.8)$ & $42(46.7)$ & & & & \\
\hline Literacy of Father & $\begin{array}{c}\text { Up to } \\
\text { Intermediate }\end{array}$ & $10(16.9)$ & $27(30.0)$ & 0.075 & 0.476 & 0.211 & 1.077 \\
\hline
\end{tabular}




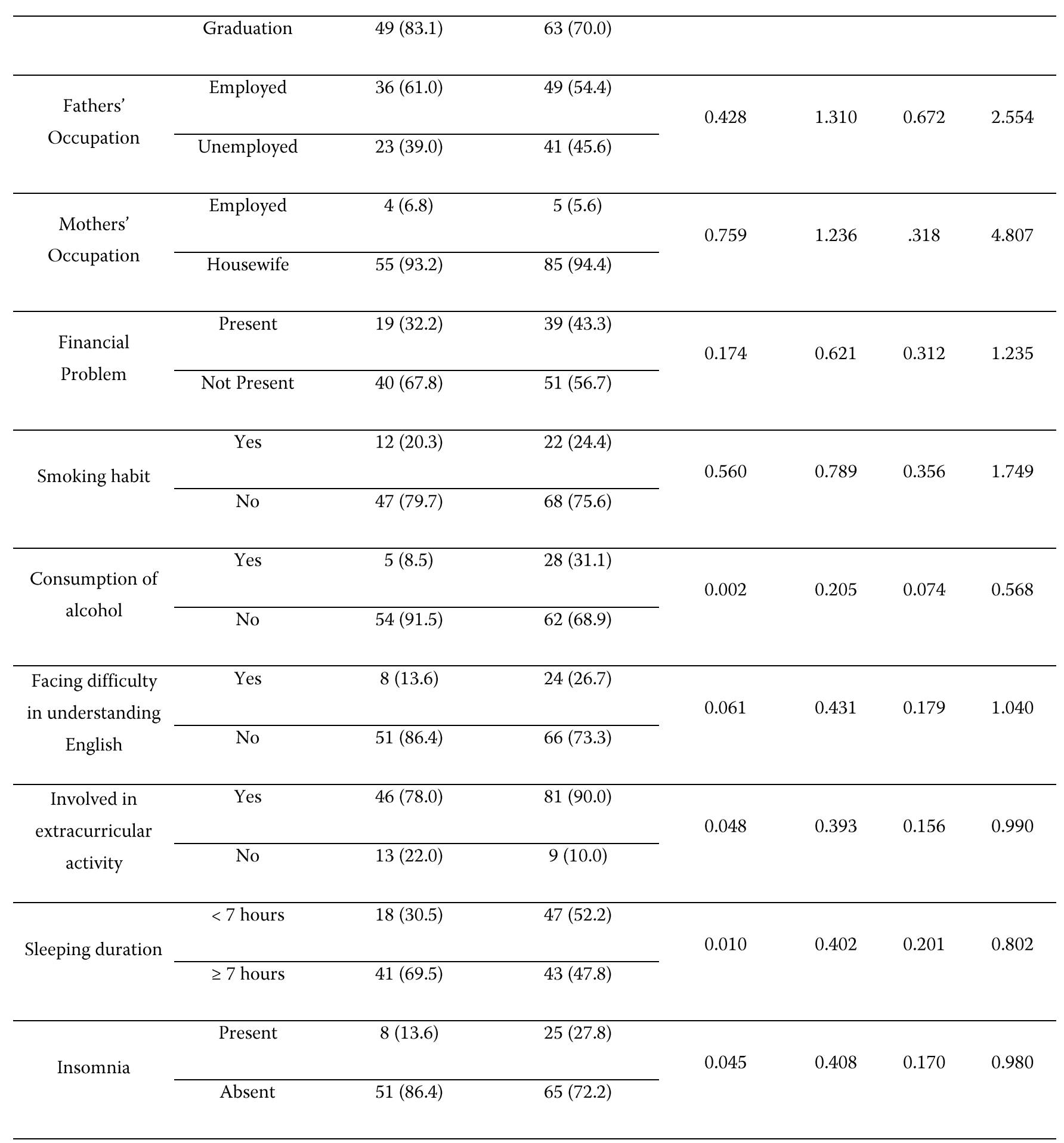

Findings in Table- 4 by analysis of multivariate binary logistic regression analysis reveals that if there was an increase in age of one-year, academic performance of students decreased by $1.8 \%$ [Adjusted odds ratio (AOR) for age $=0.982$ ] but it was not a significant predictor. Female students academically performed much better than male students (AOR $=0.080, P 0.001)$. It explains that male students had $91 \%$ less likelihood of getting good marks in their academic performance. The 
students who used to take alcohol $(\mathrm{AOR}=0.485)$ and not taking adequate sleep $(\mathrm{AOR}=0.477)$ had $50.0 \%$ less chances of performing well in their examination. There was no effect of extracurricular activity on students' academic performance. Among all independent variables which were found significant in univariate binary logistic regression analysis, only gender (P 0.001) was detected as a significant predictor in multivariate binary logistic regression analysis.

Table 4. Multivariate Binary Logistic Regression Analysis between various factors and academic performance of undergraduate medical students

\begin{tabular}{|c|c|c|c|c|c|c|c|c|c|}
\hline \multirow{3}{*}{ Variables } & \multirow{3}{*}{ Sub-group } & \multirow{3}{*}{$\beta$} & \multirow{3}{*}{ S.E. } & \multirow{3}{*}{ Wald } & \multicolumn{3}{|c|}{ Significant } & \multirow[t]{2}{*}{$95 \% \mathrm{Cl}$ for } & \multirow[t]{2}{*}{$\operatorname{EXP}(\beta)$} \\
\hline & & & & & df & \multirow[b]{2}{*}{ (Pvalue) } & \multirow[t]{2}{*}{$\operatorname{Exp}(\beta)$} & & \\
\hline & & & & & & & & Lower & Upper \\
\hline \multirow[t]{2}{*}{ Age } & - & -0.018 & 0.127 & 0.021 & 1 & 0.885 & 0.982 & 0.765 & 1.260 \\
\hline & Male & & & & & & & & \\
\hline \multirow[t]{2}{*}{ Gender } & & -2.452 & 0.494 & 24.689 & 1 & 0.000 & 0.086 & 0.033 & 0.227 \\
\hline & Female & & & & & & & & \\
\hline \multirow{3}{*}{$\begin{array}{l}\text { Education taken up } \\
\text { to class } 12^{\text {th }}\end{array}$} & Rural & & & & & & & & \\
\hline & & -0.203 & 0.446 & 0.208 & 1 & 0.648 & 0.816 & 0.341 & 1.955 \\
\hline & Urban & & & & & & & & \\
\hline \multirow[t]{2}{*}{ Alcohol } & Present & & & & & & & & \\
\hline & & -0.724 & 0.657 & 1.213 & 1 & 0.271 & 0.485 & 0.134 & 1.758 \\
\hline consumption & Absent & & & & & & & & \\
\hline \multirow{3}{*}{$\begin{array}{c}\text { Extracurricular } \\
\text { activity }\end{array}$} & Present & & & & & & & & \\
\hline & & 0.014 & 0.605 & 0.001 & 1 & 0.982 & 0.1014 & 0.310 & 3.319 \\
\hline & Absent & & & & & & & & \\
\hline \multirow{3}{*}{ Sleeping duration } & $<7 \mathrm{hrs}$ & & & & & & & & \\
\hline & & -0.740 & 0.443 & 2.796 & 1 & 0.094 & 0.477 & 0.200 & 1.136 \\
\hline & $>7 \mathrm{hrs}$ & & & & & & & & \\
\hline \multirow[t]{2}{*}{ Insomnia } & & 0.020 & 0.597 & 0.001 & 1 & 0.974 & 1.020 & 0.317 & 3.284 \\
\hline & Absent & & & & & & & & \\
\hline \multicolumn{2}{|l|}{ Constant } & 2.089 & 3.138 & 0.443 & 1 & 0.506 & 8.073 & & \\
\hline
\end{tabular}

\section{Discussion}

In the present study to measure academic performance of the students, we used overall average score of all three years examination, same was also used by Hijazi et al (9). Present study revealed that in the 1 st professional examination,
$99(66.4 \%)$ students had scored equal to or more than $60 \%$ while in the 2 nd and 3rd professional examination only 49 (32.9\%) and 45 (30.2\%) could achieve similar performance. Despite interactive and effective teaching, their academic performance declined with time. This may be due 
the fact that, in the first year, the students are more enthusiastic and keener to study about medical sciences, but as they step up in the second and third professional, their interest in academics decreases and they get relaxed after completing the vast syllabus of first year. Probably some other factors like excess use of mobile and internet (30.2 $\%$ spend their time $<4$ hours on social networking while $69.8 \%$ pass time on social networking $>4$ hours), and findings that $85.2 \%$ were involved in the extracurricular activities also play a key role in the declining of their academic performance. Now-a-days, it has been observed that the students also join online coaching classes of PG entrance examination from second professional onwards. Arora $\mathrm{N}$ et al (6) also reported similar findings in their study that distraction factors were the second most common factor that affect students' performance. On the other hand, the findings of study conducted by Batool $\mathrm{H}$ et al (10) were contradictory to our findings. They reported that the students scored more percentage of marks in final professional year as compared to first or second-year professional examination.

It was revealed in the present study that female students performed better than male $(\mathrm{COR}=$ $0.066, P 0.001)$. Mandal A et al (8) and Roy SS et al (11) observed similar findings in their studies that males performed worse than female in the test ( COR $=0.2194,95 \%$ CI 0.08069-0.5968, P 0.001) and the average examination performance of the female group was significantly better compared with the male students $\left(\begin{array}{ll}P & 0.01\end{array}\right)$ respectively. A study conducted by Sudhir PK et al (12) in government medical universities in Kerala supported these findings that female students outperformed their male peers which explains that the female students are more punctual (less absenteeism from lectures and laboratory work), attentive, consistent and self-disciplined towards their studies as compared to male students.

It was observed in the present study that those students who were competent in English language had good academic performance as compared to those students who were facing difficulty in speaking, writing an understanding English. Harb et al (13) reported similar finding in their study that most important factor for good academic performance was effectuality in English language. A study done by Mandal et al (8) confirmed these findings in their study, that those students who were instructed in their native language during admission time had poor academic performance and mentioned that $14 \%$ of study population faced difficulty in understanding English. There are many studies suggesting that the most important predictor of performance in medical school is both prior academic achievement and English language in fluency (14-16).

Present study showed that those students whose fathers were employed performed good in their academic performance as compared to those whose fathers were unemployed. Similar findings were also observed in a study conducted by Usain $M$ et al (17). It has also been observed that the students who come from a financially secured family have a better performance in university as they are more confident to gather knowledge and are focused towards their goal (18).

Present study revealed that the students who were not suffering from insomnia and sleeping hours $>7$ hours were able to perform well in their examinations. It was supported by a study conducted by Singh R et al (19) who observed positive correlation between sleeping hours and academic performance, Chung KF et al (20) stated that the students who used to sleep less in working days had poor performance and Bahammam AS et al (21) showed that academic performance is associated with the timing of sleep and wakefulness and not with total sleep duration. On the other hand, Al Khani AM et al (22) reported that almost $60 \%$ of the poor sleepers were high achievers.

\section{Conclusion}

Academic success of medical students is affected by a number of factors. In the present study, the academic performance was found to decrease with advancement in the professional year of their medical course and some nonmodifiable and modifiable factors such as female students, schooling up to class 12th from urban area, educated parents with graduation, students 
whose father had formal job, no history of taking alcohol, adequate sleep and those who were more focused towards study which have great impact on the academic performance of the students were also detected. These factors can be dealt accordingly by the institutional authorities to have better academic performance of the students in their professional carrier.

Limitations of the study: The main limitation of the study was that only quantitative data in the form of marks obtained in the examinations held at the end of each professional year was considered to assess the academic performance; along with this qualitative data could have also been collected by conducting focussed group discussions among the study subjects to find out the various determinants of their academic performance.

Application of the findings: The findings of the study will help in enhancing the measures taken at the institution level to improve the academic performance of medical graduates.

Funding: Self-funded

\section{Acknowledgments}

All authors for contributing equally in preparing the manuscript.

Conflicts of Interest: The authors declare that there are no conflicts of interest. None declared by the authors.

\section{References}

1. Ali N, Jusoff K, Ali S, Mokhtar N, Salamat ASA. The factors influencing students' performance at University Technology, MARA Kedah, Malaysia. Manage Sci Eng. 2009; 3(4):81-90.

2. Bassaw B, Pitt-Miller P. Modernizing medical education perspective from a developing country. West Indian med J. 2007;56(1):80-5.

3. Venkatashivareddy B, Gupta A, Singh AK. A study to assess factors affecting the performance of undergraduate medical students in academic examination in community medicine. Int $J$ Community Med Public Health. 2017; 4(4):10661070 .

4. Olufemi OT, Adediran AA, Oyediran WO. Factors affecting students' academic performance in colleges of education in south west, Nigeria. $\mathrm{Br} J$ Educ. 2018; 16(10):43-56.

5. Rasula S, Bukhshb Q. A study of factors affecting students' performance in examination at university level. Procedia-Social Behav Sci. 2011;15:2042-7.

6. Arora N, Singh N. Factors affecting the academic performance of college students. Manage $J$ Educ Technol. 2017; 14(1):47-53.

7. Mushtaq I, Khan SN. Factors affecting students' academic performance. Global J Manage Bus. 2012;12(9):17-22.

8. Mandal A, Ghosh A, Sengupta G, Bera T, Das N, Mukerjee $S$. Factors affecting the performance of undergraduate medical students: perspective. Indian J Community Med. 2012; 37(2):126-129.

9. Hijazi ST, Naqvi SMMR. Factors affecting students' performance. A case of private college. Bangladesh e J Sociol. 2006; 3(1):65-99.

10. Batool H, Mumtaz A, Chaughtai AS, Sadaqat A, Shah SIA. Academic Performance: A descriptive study based on academic performance of MBBS students of central park medical college over a period of 5 years. Prof Med J. 2017; 24(11):17331739.

11. Roy SS, Chadalawada J. Predictors of academic performance of medical undergraduate students of microbiology class in Kolkata. Int J Med Public Health. 2014;4(4):392-395.

12. Sudhir PK, Varghese KG, George B. Evaluation of academic performance of undergraduate dental students in a government medical university in Kerala, India. Indian J Dent Res. 2019;30(2):175-179.

13. Harb N, El-Shaarawi A. Factors affecting students' performance. MPRA. 2006:1362.

14. Alfayez SF, Strand DA, Carlin JD. Academic social and culture factors influencing medical students grade performance. Med Educ. 1990; 24(3):230-238. 
15. House JD. The independent effect on student characteristics and instructional activities on achievements: An application of inputenvironment - output assessment model. Int $J$ Instructional Media. 2002;29(2):225-239.

16. Crede R, Kuncel NR. Study habits, skills and attitude: The third pillar supporting collegiate academic performance. Perspect Phsychol Sci. 2008;3(6):425-453.

17. Usaini MI, Abubakar NB. The impact of parents' occupation on academic performance of secondary school students in Kuala Terengganu. Multilingual Acad J Educ Social Sci. 2015;3(1):112-120.

18. Essays UK. Why is academic success important? [Internet]. November 2018. [Accessed 28th May 2020]; Available from: https://www.ukessays.com/essays/education/whyis-academic-success-important-educationessay.php?vref=1.q
19. Singh R, Sharma R, Suri JC, Das S. Impact of sleep pattern on mood and academic performance of medical students. Indian J Sleep Med. 2009; 4(2):6167.

20. Chung KF, Cheung MM. Sleep-wake up patterns and sleep disturbances among Hong Kong Chinese adolescents. Sleep. 2008; 31(2):185-194.

21. Bahammam AS, Alaseem AM, Alzakri AA, Almeneessier AS, Sharif MM. The relationship between sleep and wake habits and academic performance in medical students: A cross-sectional study. BMC Med Educ. 2012; 12:61.

22. Al Khani AM, Sarhandi MI, Zaghloul MS, Ewid M, Saquib N. A cross sectional survey on sleep quality, mental health, and academic performance among medical students in Saudi Arabia. BMC Res Notes. $2019 ; 12: 665$. 